\section{Elected body goes out fighting}

Tokyo

THE Science Council of Japan (JSC)'s final meeting as a directly elected body ended last week in the liberal tradition it has long upheld. One of its final actions was to call on the government to improve the status of female scientists.

Since 1948, Japan's unique "Parliament of Scientists" has provided a means for Japanese research workers to express their opinions to government. Every three years, 210 representatives from every branch of science have been elected to the council by a direct vote of more than 200,000 of Japan's scientists. Committees organized by the council have been instrumental in shaping the grants policy of the Ministry of Education, Culture and Science (MESC), in pressing for the establishment of new institutes in areas where they were thought most needed and in upholding scientists' rights. The president of JSC is automatically a member of the Council for Science and Technology, the highest science policy-making body in the land, and thus has the ear of the Prime Minister.

In recent years, however, things have not always gone smoothly between the government and JSC. As MESC relied more and more on advice from its own internal science council, JSC came to see its influence on grant policy decline. In turn, voters became apathetic and, as the government sees it, the council came to be influenced more by those with a "political" axe to grind than by those concerned with purely scientific matters. Apparent opposition to nuclear power by JSC particularly irritated the government.

In 1982, the government, which pays all JSC's expenses, finally demanded reform, and when it proved hard to agree, reform was forced on JSC. The result is that from now on, members will no longer be directly elected but will instead be appointed through the scientific societies (see Nature 305, 361; 1983).

The call to improve the lot of women scientists stems from surveys carried out by JSC over the past few years of the special difficulties encountered by women scientists. It was plain that few women were reaching the top posts: there are no female full professors in the science faculties of the principal universities, few women among the laboratory chiefs of government research institutes and a relatively small percentage of women entrants to science courses in top universities.

These observations mirror problems for women in Japanese society as a whole. The average salaries of women are barely half those of men, not so much because of different rates of pay for the same job but because women generally occupy lower positions. Surveys show that three-quarters of companies hiring university graduates (who will eventually go into management posi- tions) hire only men. Of those that do hire women, half will not allow them any possibility of promotion and two-thirds will not give them access to training or education programmes. "Retirement" at marriage is a not unusual condition of work.

JSC's subcommittee on the status of female researchers carried out its own survey on the position of women scientists after an earlier plea, in 1977 , failed to persuade the government to conduct a proper survey. Some 2,000 women scientists and 1,400 male scientists were asked to complete questionnaires, and the results confirm women's poor promotion prospects.

Taking into account academic record, the chances of a woman becoming a full professor appear much lower than those for a man. Most women who successfully complete their doctorates cannot hope to gain a post higher than assistant lecturer and the higher they go, the more difficult further promotion becomes. Professor Katsuko Saruhashi, one of the few women to reach laboratory director level (within the govern-

\section{Romania}

PRESIDENT Nicolae Ceaucescu of Romania last month cut short an official visit to Canada after he was told that he could not visit the Pickering nuclear reactor plant because of a labour dispute. He did, however, visit Hydro-Quebec's nuclear power station at Becancour, which uses Candu reactors, similar to those the official handouts somewhat misleadingly referred to the "two plants now under construction in Romania".

Romania signed contracts for the purchase of two Candu reactors in 1978 and 1981 , and has options on up to eight more. But the deal has been beset by difficulties; firstly by Romania's lack of hard currency, which makes necessary a countertrade (barter) arrangement, and then because the Romanians insisted on dealing with all the Canadian subcontractors separately, instead of negotiating with Atomic Energy of Canada Ltd (AEC). As a result, although the proposed site at Cernavoda in Romania is being prepared to receive five reactors, hardly any equipment has yet arrived from Canada. The 4,500 Romanian on-site workers are simply carrying out preliminary construction work, including the containment buildings for the firt two Candus. (Containment buildings are a rarity in East European power stations; Soviet doctrine considers them a Western device to raise costs, although the Hungarians insisted on having them for their Soviet-produced reactors at Paks.)

$\mathrm{Mr}$ Ceaucescu is clearly anxious to get the Candus installed as soon as possible. Although Romania is an oil-producing @ 1985 Nature Publishing Group

ment's Meteorological Research Institute) and a veteran campaigner for the rights of women scientists, says it is bad for the nation not to make use of women's abilities and that what is now being demanded is a proper government survey that could be used to make the reforms that would improve the position of women.

On the government's recent record, however, it is unlikely that her wishes will be fulfilled. The Diet will vote next month on an equal opportunities bill intended to give the government an opportunity to ratify the United Nations Convention on the Elimination of All Forms of Discrimination Against Women. The bill has, however, been thoroughly emasculated by employers' representatives, and apart from abolishing some old restrictions, such as those that prevent women working late at night, it provides little in the way of new rights. There are so many loopholes in the bill that it would be almost impossible for legal action to be taken on its provisions. Although it calls for women to be given equal treatment to men in job recruitment, allocations and promotion, there are no substantial penalities for non-compliance.

Alun Anderson

\title{
Nuclear power in the distance
}

country, heavy investment in the petrochemical industry during the 1970s has turned it into a net energy importer. By the early 1980 s there was an energy crisis, and the severe winter of 1984-85 meant prolonged power cuts for both domestic and industrial users and a ban on all private motoring. Not surprisingly, the Party daily, Scintea, on the eve of the President's visit to Canada, hailed the Candu as the answer to Romania's energy problems.

The project is, of course, badly behind schedule. The first two Cernavoda Candus were meant to be operational by 1985 ; instead, the first major equipment will not be delivered until the autumn, and the primary cooling pumps, from Bingham Willamette of British Columbia, will not be delivered for two or three years.

But Canada too needs the Romanian contract to save jobs in its nuclear industry. Although the existing deals provide for Romania gradually to absorb Canadian technology and eventually to build its own Candu reactors (paying a royalty on the first fifteen), the Canadian content of the third and fourth Cernavoda reactors, though less than the first two, would still be significant. Furthermore, after prolonged negotiations, the two sides have signed a third-market contract, by which (subject to Canadian requirements on non-proliferation), Romania would cooperate with Canada in selling Candu reactors to other countries, particularly in the socialist and non-aligned blocs where Romanian contacts could be particularly useful.

Vera Rich 